\title{
Analysis of the R72P polymorphism of the TP53 gene in patients with invasive ductal breast carcinoma
}

\author{
MÁRCIA PORTELA DE MELO ${ }^{1}$, ANA CRISTINA BITTELBRUNN ${ }^{2,3}$, CARLOS HENRIQUE MENKE ${ }^{2,3}$, \\ DIEGO DE MENDONÇA UCHOA ${ }^{4}$, LUCIANA GRAZZIOTIN ROSSATO ${ }^{3}$, \\ GUSTAVO LUCENA KORTMANN $^{3}$ and SANDRA LEISTNER-SEGAL ${ }^{1,3,5}$ \\ ${ }^{1}$ Postgraduate Program in Medical Sciences, Federal University of Rio Grande do Sul, \\ ${ }^{2}$ Mastology Service, ${ }^{3}$ DNA/Breast and Ovary Tissue Bank, HCPA Research Center, ${ }^{4}$ Pathology Service, \\ ${ }^{5}$ Medical Genetics Service, Hospital de Clínicas de Porto Alegre, Porto Alegre, RS, Brazil
}

Received November 26, 2008; Accepted May 21, 2009

DOI: 10.3892/mmr_00000174

\begin{abstract}
Breast cancer is the most common neoplasia as well as the main cause of cancer-related death among women, experiencing a $0.5 \%$ increase in incidence per year. The disease results from a series of mutations in the DNA development and repair genes. Approximately 50\% of human carcinomas present mutations in the TP53 gene. Polymorphisms of TP53 include codon 72 containing either arginine (CGC) or proline (CCC). Such polymorphisms may be involved in the susceptibility and predisposition to cancer, presenting a widely variable ethnic and geographic distribution. The arginine homozygous genotype seems to be a significant risk factor for breast cancer. The purpose of this study was to determine the frequency of the R72P polymorphism of the TP53 gene in patients with invasive ductal breast cancer from southern Brazil, where this type of cancer has a high incidence, as well as its association with breast carcinoma and clinicopathological characteristics. Seventy-six patients suffering from invasive ductal breast cancer and 80 controls were analyzed, and samples were evaluated by PCR followed by restriction enzyme digestion. No statistical differences in terms of the genotype frequency $(\mathrm{P}=0.707)$ or the arginine and proline allele frequencies $(\mathrm{P}=0.469)$ involving codon 72 were found in patients compared to controls. Thus, statistical analysis did not suggest any association between the R72P polymorphism of the TP53 gene and invasive ductal carcinoma in the population studied. Additionally, no significant association with the clinicopathological characteristics presented by the breast carcinoma patients was found.
\end{abstract}

Correspondence to: Dr Sandra Leistner-Segal, Medical Genetics Service, Hospital de Clínicas de Porto Alegre, Rua Ramiro Barcelos 2350, CEP 90035-903, Porto Alegre, RS, Brazil

E-mail: ssegal@hcpa.ufrgs.br

Key words: gene, TP53, R72P polymorphism, polymerase chain reaction, breast carcinoma

\section{Introduction}

Breast cancer is the most common neoplasia (23\% of all carcinomas) as well as the main cause of cancer-related death among women. Since 1990, there has been a $0.5 \%$ increase in the incidence of breast cancer per year. This rate of growth allows an estimate of 1.4 million new cases by 2010 (1). Among Brazilian women, breast cancer is the most common cancer, with the exception of non-melanoma skin cancer. According to data from the National Cancer Institute (INCA), an estimated 49,400 new cases will arise in 20082009 (2).

Breast carcinoma results from a series of mutations in the DNA development and repair genes (3). The activation of cell proto-oncogenes and the inactivation of tumor suppressor genes are the main genetic changes involved in tumor development (4). The heterogeneity of the clinical behavior of breast cancer suggests that its genetic basis may vary (3). Although the early stages of the disease and the pathways of carcinogenesis are poorly defined, invasive carcinoma seems to evolve from an in situ component (5). The clonal and evolutionary relationship between genetic and phenotypic variation is demonstrated not only by the coexistence of two types of lesion, but also by histological similarities between invasive and in situ components within the same lesion (5), and by the presence of chromosomal changes shared by ductal carcinoma in situ (DCIS) and invasive carcinoma (6).

The TP53 tumor suppressor gene is mutated in approximately $25 \%$ of DCIS, but is rarely mutated in normal breast tissue or benign proliferative lesions (6). The frequency of such mutations progressively increases from low-grade DCIS, reaching $40 \%$ in high-grade DCIS $(7,8)$. Thus, changes in genetic expression in carcinogenesis seem to occur during the transition from normal breast tissue to DCIS (6).

Chromosomal instability, with the gain or loss of multiple loci, occurs as hyperplastic lesions progress from DCIS to invasive ductal carcinoma (9). This indicates that changes in TP53 play an important role in the process of breast carcinogenesis $(7,8)$. 
The tumor suppressor gene TP53, located on chromosome 17 (17p13.1), encodes a phosphoprotein that participates in the cell cycle (10). More than 15,000 inactivating mutations in TP53 gene alleles have been identified, the majority of these being missense mutations (11). Approximately $80 \%$ of these mutations are grouped between exons 5 and 8 (12), and change the conformation, specificity and linking sequence to DNA and its role as a transcription factor (11). As a result, synthesis occurs in a stable, non-functional and non-degradable protein that accumulates in the tumoral cells and is detectable by immunohistochemistry (13).

Approximately $50 \%$ of human carcinomas present mutations in the TP53 gene, with ensuing loss of function of the p53 protein, which it encodes $(7,12,24)$. In sporadic breast carcinomas, these mutations have been identified in $20-50 \%$ of cases, with a marked geographical heterogeneity in our Brazilian population $(12,15-17)$, and with the loss of the wild-type allele; that is, loss of heterozygosity (18). A number of studies have examined the association of mutations in TP53 with different clinical phenotypes in breast carcinoma. The majority of these studies found the presence of mutations to be associated with reduced patient survival (7).

Protein p53 has been called the 'guardian of DNA integrity', acting as a transitional regulator induced in response to DNA damage, which may lead to the subsequent interruption of the cell cycle or the induction of apoptosis in response to the depletion of metabolites, thermal shock, hypoxy, viral oncoproteins and activated cell oncogenes (4,12,19-22).

The TP53 gene is polymorphic in codon 72 for the protein it encodes at nucleotide $215(14,23)$, with a variable base pair transition $(\mathrm{g} .215 \mathrm{G} \rightarrow \mathrm{C})$ in exon 4 , resulting in the replacement of proline for arginine in the proteic sequence $(8,24,26)$. Thus, p53 may contain an arginine (CGC) or proline (CCC) codon in this position, resulting in the susceptibility or predisposition to cancer. It is possible to identify polymorphisms by the use of restriction enzymes $(10,23,26-28)$. This polymorphism features a widely variable ethnic and geographic distribution (14), and has been studied in several tumors; not only those of the breast, but also those of the lung, colon, stomach and bladder (29).

The TP53 gene with the proline (Pro72) allele is structurally different from TP53 with the arginine (Arg72) allele. Tumors that contain cells with Pro72 in TP53 are slower to develop and smaller than tumors containing Arg 72 cells. Both human TP53 polymorphic forms appear to participate in breast cancer carcinogenesis $(12,14,23)$. The Arg72 TP53 form is considered to be more oncogenic $(14,30)$, and is significantly associated with a higher frequency of mutations in the TP53 gene in tumors where it is present (23).

Migration together with large territorial expansion has contributed greatly to the diversity and complexity of the ethnic composition of the Brazilian population (31). In contrast to other regions of the country, the southern region of Brazil comprises a population of mainly European descent (31) and manifests the second highest incidence of neoplasias in the country (2). This study aimed to evaluate the frequency of the R72P polymorphism of the TP53 gene in patients with invasive ductal breast cancer in the state of Rio Grande do Sul, Brazil, as well as the association of this polymorphism with breast carcinoma and clinicopathological characteristics.

\section{Materials and methods}

Patients and controls. Samples $(10 \mathrm{ml})$ of peripheral blood in EDTA were collected from 76 patients with invasive ductal carcinoma confirmed by anatomopathological examination who were treated and followed up by the Mastology Service of the Hospital de Clínicas de Porto Alegre (HCPA) at any stage of the disease. The control consisted of blood samples taken from 80 healthy donors recruited from the HCPA Blood Bank. DNA was extracted from the peripheral blood by means of the salt precipitation procedure described by Miller (32), and was kept frozen at $-20^{\circ} \mathrm{C}$ until use.

Patients were consecutively enrolled at the time of presurgical evaluation. During this consultation, demographic data, hormonal factor data, family history of carcinoma and history of benign breast disease were collected by questionnaire. Following surgery, data regarding the breast carcinomas were collected by routine anatomopathological examination and immunohistochemistry performed by the HCPA Pathology Service.

This study was approved by the Scientific and Ethical Committee of the Research and Postgraduate Group at the HCPA (project no. 05-551). Procedures were performed with the informed consent of the patients.

Amplification of genetic material using polymerase chain reaction. Exon 4 of the TP53 gene was amplified by polymerase chain reaction (PCR) using $5 \mu \mathrm{l}$ of $\mathrm{dNTP}$ (Sigma), $5 \mu \mathrm{l}$ ammonia buffer [16 $\mathrm{mM}\left(\mathrm{NH}_{4}\right)_{2} \mathrm{SO}_{4}, 67 \mathrm{mM}$ Tris-HCL (pH 8.8) and $0.1 \%$ Tween-20], $0.2 \mu \mathrm{l}$ Taq DNA polymerase (Gibco), $1.5 \mu 1 \mathrm{MgCl}_{2}$, $1.5 \mu \mathrm{l} \mathrm{BSA}$ and $1.0 \mu \mathrm{l}$ of specific primers for the fragment, amplified to a final volume of $50 \mu$ l. The PCR primers used were previously described (33).

PCR conditions consisted of an initial denaturation at $94^{\circ} \mathrm{C}$ for $3 \mathrm{~min}$, followed by 35 cycles at $94^{\circ} \mathrm{C}$ for $40 \mathrm{sec}$, annealing at $56^{\circ} \mathrm{C}$ for $30 \mathrm{sec}$, extension at $72^{\circ} \mathrm{C}$ for $1 \mathrm{~min}$ and a final extension at $72^{\circ} \mathrm{C}$ for $10 \mathrm{~min}$. The amplified 350-bp fragment was identified by $1.5 \%$ agarose gel electrophoresis stained with ethidium bromide.

Restriction enzyme digestion for the R72P polymorphism. To identify the exon 4 R72P polymorphism, the PCR product was digested with $0.5 \mu \mathrm{l}$ of the $B s t \mathrm{UI}$ restriction enzyme (New England Biolabs), $3 \mu$ l buffer [10 mM Tris-HCL (pH 7.5), $7 \mathrm{mM} \mathrm{MgCl}$, $60 \mathrm{mM} \mathrm{NaCl}, 7 \mathrm{mM}$ 2-mercaptoethanol and $0.01 \% \mathrm{BSA}$ ] and $10 \mu \mathrm{l}$ of the PCR product for a final volume of $30 \mu \mathrm{l}$. The tubes were incubated at $60^{\circ} \mathrm{C}$ in a thermocycler for $2 \mathrm{~h}$ until fully digested. The digestion reaction was viewed by electrophoresis in 3\% agarose gel stained with ethidium bromide.

The restriction enzyme $B s t \mathrm{UI}$ recognizes the $\mathrm{CG} \rightarrow \mathrm{CG}$ site, cleaving the 350-bp fragment into 191 and $159 \mathrm{bp}$, respectively, in the presence of the arginine allele (CGC). The proline allele (CCC) does not feature the restriction site and is therefore not cleaved, remaining at $350 \mathrm{bp}$.

Statistical analysis. Absolute and relative frequencies were used to calculate differences between the patient and control samples. The $\chi^{2}$ Pearson test was used to assess whether the groups were in Hardy-Weinberg equilibrium and to identify 
Table I. Genotype frequency of the R72P polymorphism in the TP53 gene in patients with invasive ductal breast carcinoma and controls.

\begin{tabular}{|c|c|c|c|c|}
\hline & \multicolumn{2}{|c|}{ Homozygotes } & \multirow{2}{*}{$\frac{\text { Heterozygotes }}{\text { Arg/Pro }}$} & \multirow[b]{2}{*}{ P-value } \\
\hline & Arg/Arg & Pro/Pro & & \\
\hline Patients $(\mathrm{n}=76)$ & $34(44.7 \%)$ & $9(11.8 \%)$ & $33(43.4 \%)$ & 0.707 \\
\hline Controls $(\mathrm{n}=80)$ & $31(38.8 \%)$ & $12(15.0 \%)$ & $37(46.3 \%)$ & \\
\hline Total $(n=156)$ & 65 & 21 & 70 & \\
\hline
\end{tabular}

$\chi^{2}, 0.693$

Table II. Allele frequency of the R72P polymorphism in the TP53 gene in patients with invasive ductal breast carcinoma and controls.

\begin{tabular}{lcccc}
\hline & $\mathrm{f}(\mathrm{R})$ & $\mathrm{f}(\mathrm{P})$ & Total alleles & P-value \\
\hline Patients $(\mathrm{n}=76)$ & $101(66.4 \%)$ & $51(33.6 \%)$ & 152 & 0.469 \\
Controls $(\mathrm{n}=80)$ & $99(61.9 \%)$ & $61(38.1 \%)$ & 160 & \\
Total & 200 & 112 & 312 & \\
\hline
\end{tabular}

$\chi^{2}$ with Yates' correction, 0.523 .

the presence of differences in relation to the genotype and allele frequency between the patients and controls. The $\chi^{2}$ Pearson test with Yates' correction was used when appropriate. Statistical significance was defined as $\mathrm{P}<0.05$. The association between the R72P polymorphism in TP53 and the clinicopathological characteristics of breast carcinoma was assessed using the $\chi^{2}$ Pearson test (categorical variations). The association of allele frequency with data from the literature was assessed by the $\chi^{2}$ Pearson test with Yates' correction. Statistical analysis was performed with SPSS 12.0 (for Windows) and Pepi version 4.0.

\section{Results}

The 76 patients with histological confirmation of invasive ductal carcinoma had an average age of $53.2 \pm 13.2$ years. The vast majority were self-declared Caucasians (64.5\%). Among the patients, $15(19.7 \%)$ had a significant family history for the risk of developing breast carcinoma (considering firstdegree relatives affected). None of the patients in menopause were undergoing hormonal therapy. Following the surgical procedure, tumor stage was determined by anatomopathological examination according to the criteria of the AJCC classification (American Joint Committee on Cancer), 6th edition. Tumor stage was distributed as follows: stage I, $27.6 \%$ of cases; stage IIA, $28.9 \%$; stage IIB, $23.7 \%$; stage IIIA, $15.8 \%$; stage IIIC, $3.9 \%$.

Histological grade was determined according to Nottingham Prognostic Index, and each patient was assigned to one of three prognostic groups: $12(15.8 \%)$ patients to the favorable prognostic group, $46(60.5 \%)$ to the moderate prognostic group

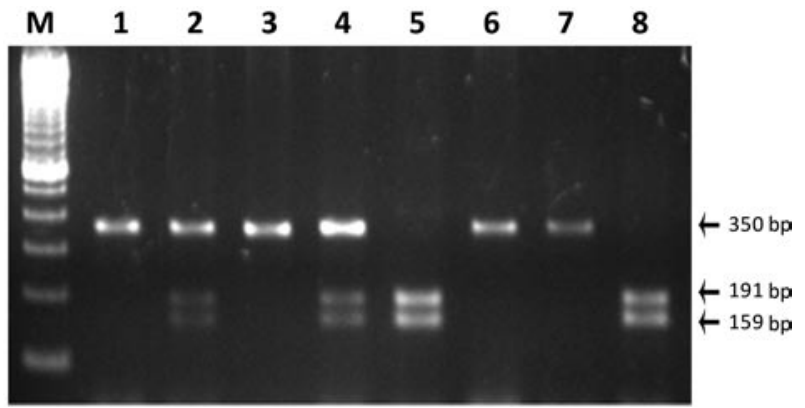

Figure 1. Agarose gel (3.0\%) showing digestions carried out with Bst UI. Lane M, 100-bp molecular weight marker. Lanes 1, 3, 6 and 7, allelic patterns of Pro/Pro; lane 2 and 4, allelic patterns of Arg/Pro; lanes 5 and 8, allelic patterns of Arg/Arg, for the R72P polymorphism of TP53.

and $13(17.1 \%)$ to the poor prognostic group. It was not possible to assess the histological grade of 5 patients due to the effects of postneoadjuvant chemotherapy.

The methodology presented was adequate for the amplification of exon 4 of the TP53 gene, having been tested in a previous study (33). The distribution of genotypes in codon 72 of TP53 was in Hardy-Weinberg equilibrium in both patients and controls. Data were analyzed in terms of the genotype (Table I) and allele (Table II) frequencies. The frequency found for the $\mathrm{R} 72 \mathrm{P}$ polymorphism was similar in the invasive ductal carcinoma patients and controls, with no significant difference found for the genotype $(\mathrm{P}=0.707)$ or allele frequency $(\mathrm{P}=0.469)$. Fig. 1 shows the results of the $B s t \mathrm{UI}$ digestion, indicating the possible alleles.

No significant association was found between the R72P polymorphism and the clinicopathological characteristics of the invasive ductal carcinoma patients. These results were compared with data in the literature, and no significant differences were found between the polymorphic allele frequencies, with the exception of two studies on a population of Ashkenazi Jews (34) and Greek women (28) $(\mathrm{P}<0.001)$, respectively.

\section{Discussion}

The mechanisms involved in the carcinogenesis of different neoplasias have been studied extensively worldwide. Research is being carried out to elucidate the genetic, enzyme and protein variations that may be involved in the progression from a normal to a neoplastic cell. Genetic changes such as mutations and various polymorphisms can involve any DNA region, which in many cases leads to a cascade of events culminating in an increase in susceptibility to neoplasia development and the appearance of biological and clinical pathological changes that are characteristic of each tumor.

Many studies suggest an association between the polymorphism in codon 72 of gene TP53 and carcinogenesis, including several human carcinomas such as cervical $(35,36)$, lung (37,38), colorectal (39), bladder (40), skin (41) and breast $(14,30,42-45)$ cancer. However, the results regarding this polymorphism are controversial. In 2002, Soulitzis et al reported a correlation between the R72P polymorphism in gene TP53 and bladder cancer, providing evidence that this polymorphism is related to the carcinogenesis of the neoplasia. The presence of 
the Arg/Arg genotype may thus be related to an increased risk of developing bladder cancer (40).

The R72P polymorphism seems to influence the expression of protein p53 (46), since it occurs within the transactivation domain of $\mathrm{p} 53$. Codon 72 is located in the hydrophobic region of the protein, which determines its conformation, link to DNA and transcriptional activity (14). Recently, differences in p53 activity have led to the study of the frequency of the polymorphism in codon 72 of the TP53 gene $(23,30,40,46)$.

A 7-fold increase in the risk of developing human papillomavirus-associated cervical carcinoma was reported in homozygous patients with the arginine allele in codon 72 compared to patients who presented one or more proline alleles in TP53 codon 72 (35). In vitro studies indicate that protein p53 containing arginine is more prone to suffering degradation due to the HPV E6 oncoprotein (36).

The results presented in this study do not reflect a statistically significant difference for genotype and allele frequencies of $\mathrm{R} 72 \mathrm{P}$ in invasive ductal carcinoma patients compared to controls. Thus, the R72P polymorphism in TP53 was not associated with an increased risk of developing invasive ductal carcinoma in the population studied. Although there was no difference between the groups, the arginine allele in codon 72 was the most common in both groups, in agreement with most studies (12).

These findings are in disagreement with various studies, which found a significant difference between the frequency of the Arg/Arg genotype in codon 72 in breast carcinoma patients and controls $(14,23,24,28,30,34,47)$, including one study carried out in the same region as the present one (47). They are also in disagreement with the results of studies in which the Pro/Pro genotype was observed more frequently in patients with breast carcinoma than in contols $(42,48)$.

However, our data were consistent with those found in similar studies carried out with Turkish, Japanese and Russian breast carcinoma patients, which did not show differences in the distribution of the three genotypes (Arg/Arg, Arg/Pro, Pro/Pro) between cases and controls $(29,49,50)$. Similar results were also found in some studies involving colorectal carcinoma, in which no association was found between the different genotypes (39).

In the US, the codon 72 polymorphism was identified as an independent risk factor for breast carcinoma in African Americans and Hispanics, but had only borderline significance in Caucasians $(\mathrm{P}=0.054)(51)$, with the arginine allele being more frequent in Caucasians and Hispanics, and the proline allele more common among African Americans (51). Another study involving codon 72 (Arg/Pro) heterozygotes in a Chinese population found evidence of a significant increase in the expression of the arginine allele in breast carcinoma patients, though no significant difference was observed in terms of genotype frequencies in Chinese patients compared to healthy controls. This suggests that the arginine allele is involved in the carcinogenesis of breast carcinoma (24).

There was no association between the codon 72 polymorphism and the clinicopathological characteristics presented by invasive ductal carcinoma patients in the present study. This may be a consequence of the small sample size. However, no association was found in studies involving women with breast carcinoma in Greece and Turkey either. This was not the case in another study carried out in the south of Brazil. This could mean that the R72P polymorphism does not interfere with the natural history of breast carcinoma $(14,30,47)$. On the other hand, Han et al revealed that cases with Pro/Pro and Arg/ Pro genotypes in codon 72 presented a smaller number of metastases for axillary lymph nodes when compared with the homozygote cases for arginine (52).

It was not possible to analyze the relationship between survival and the studied polymorphism due to the relatively recent diagnosis of the patients in the study. However, a protective effect was observed for the death outcome among English patients suffering from breast carcinoma with the presence of the proline allele in the R72P polymorphism, though statistical significance was lost following multivariate analysis (53). These findings are contrary to those reported by Tommiska et al, who demonstrated that proline homozygote patients with breast carcinoma presented a less favorable prognosis compared to other genotypes (44).

Given that the distribution of the proline allele seems to vary among the different ethnic groups, and that the frequency of the arginine allele increases in conjunction with the distance of the analyzed population from the equator, the contradictory findings involving the R72P polymorphism in the TP53 gene and the risk of breast as well as other carcinomas may be due to interracial, ethnic and geographic variations $(12,14)$. Moreover, any change in the enzyme cleavage site may occur and lead to partial or non-digestion of the amplified fragment (exon 4). These changes can only be confirmed by DNA sequencing $(33,54)$.

In conclusion, the R72P polymorphism in the TP53 gene was not associated with an increased risk of developing invasive ductal carcinoma in the population studied. This finding may be related to the great interracial and ethnic variation in our population, derived from frequent miscegenation and exposure to different environmental factors that impact the evolution of breast cancer. Further studies are required involving larger populations to analyze the mutation in splice-sites $(7,17,23)$. Additionally, testing for loss of heterozygosity (26) and studying haplotypes involving different polymorphisms in the TP53 gene that seem to modify the risk of breast carcinoma may aid in identifying patients at a greater risk of developing the disease $(42,45)$. The applicability and generalization of the findings from this and other studies regarding the risk of breast carcinoma remain uncertain, and need to be established.

\section{Acknowledgements}

This study was supported by the Grupo de Pesquisa e Pósgraduação (GPPG), Hospital de Clínicas de Porto Alegre (HCPA) (Porto Alegre, RS, Brazil) and the Fundo de Incentivo à Pesquisa/HCPA (FIPE-HCPA).

\section{References}

1. Parkin DM, Bray F, Ferlay J and Pisani P: Global cancer statistics. CA Cancer J Clin 55: 74-108, 2005.

2. Estimativa 2008 - Incidência de câncer no Brasil. Brasília: Instituto Nacional do Câncer (INCA), Ministério da Saúde, 2005. http://www.inca.gov.br. Cited Jan. 2008.

3. Hellman S: Darwin's clinical relevance. Cancer 79: 2275-2281, 1997.

4. Elledge RM and Allred DC: The p53 tumor suppressor gene in breast cancer. Breast Res Treat 32: 39-47, 1994. 
5. Gupta SK, Douglas-Jones AG, Fenn N, Morgan JM and Mansel RE: The clinical behavior of breast carcinoma is probably determined at the preinvasive stage (ductal carcinoma in situ). Cancer 80: 1740-1745, 1997.

6. Burstein HJ, Polyak K, Wong J, Lestar SC and Kaelin CM: Ductal carcinoma in situ of the breast. N Engl J Med 350: 1430-1441, 2004

7. Gasco M, Shami S and Crook T: The p53 pathway in breast cancer. Breast Cancer Res 4: 70-76, 2002.

8. Borresen-Dale AL: TP53 and breast cancer. Hum Mutat 21: 292-300, 2003.

9. O'Connell P, Pekkel V, Fuqua SAW, Osborne CK, Clark GM and Allred DC: Amalysis of loss of heterozygosity in 399 premalignant breast lesions at 15 genetic loci. J Natl Cancer Inst 90 : 697-703, 1998

10. IARC Homepage, International Agency for Research on Cancer: p53 polymorphisms. http://www.iarc.fr/p53/index.html. Cited Nov. 2007.

11. Tanyi J, Tory K, Bánkfalvi A, Shröder W, et al: Analysis of p53 mutation and cyclin D1 expression in breast tumors. Pathol Oncol Res 5: 90-94, 1999.

12. Gallo CVM, Azevedo G, Mendonça S, Moraes E, Olivier M and Hainaut P: TP53 mutations as biomarkers for cancer epidemiology in Latin America: current knowledge and perspectives. Mutat Res 589: 192-207, 2005.

13. Geisler S, Lonning PE, Aas T, Johnsen H, Fluge O, Haugen DF, Lillehaug JR, Akslen LA and Borresen-Dale AL: Influence of TP53 gene alterations and c-erbB-2 expression on the response to treatment with doxorubicin in loally advanced breast cancer. Cancer Res 61: 2505-2512, 2001.

14. Buyru N, Tigli $\mathrm{H}$ and Dalay N: p53 codon 72 polymorphism in breast cancer. Oncol Rep 10: 711-714, 2003.

15. Sorlie T, Perou CM, Tibshirani R, et al: Gene expression patterns of breast carcinomas distinguish tumor subclasses with clinical implications. Proc Natl Acad Sci USA 98: 10869-10874, 2001.

16. Lai H, Lin L, Nadji M, Lai S, Trapido E and Meng L: Mutations in the p53 tumor suppressor gene and early onset breast cancer. Cancer Biol Ther 1: 31-36, 2002.

17. Nagai MA, Barbosa HS, Zago MA, et al: TP53 mutations in primary breast carcinomas from white and African-Brazilian patients. Int J Oncol 23: 189-196, 2003.

18. Oesterreich S and Fuqua SA: Tumor suppressor genes in breast cancer. Endocr Rel Cancer 6: 405-419, 1999.

19. Sherr CJ: The pezcoller lecture: cancer cell cycles revisited. Cancer Res 60: 3689-3695, 2000.

20. Sherr CJ and McCormick F: The RB and $\mathrm{p} 53$ pathways in cancer. Cancer Cell 2: 103-112, 2002.

21. Vogelstein B, Lane D and Levine AJ: Surfing the p53 network. Nature 408: 307-310, 2000.

22. Levine AJ, Hu W and Feng Z: The p53 pathway: What questions remain to be explored? Cell Death Differ 13: 1027-1036, 2006

23. Langerod A, Bukholm IRK, Bregard A, Lonning PE, Andersen TI, Rognum TO, Meling GI, Lothe RA and Borresen-Dale AL: The TP53 codon 72 polymorphism may affect the function of TP53 mutations in breast carcinomas but not in colorectal carcinomas. Cancer Epidemiol Biomarkers Prev 11: 1684-1688, 2002.

24. Siddique MM, Balran C, Fiszer-Maliszewska L, et al: Evidence for selective expression of the p53 codon 72 polymorphs: implications in cancer development. Cancer Epidemiol Biomarkers Prev 14: 2245-2252, 2005.

25. Martin A-M, Kanetsky PA, Amirimani B, Colligon TA Athanasiadis G, Shih HA, Gerrero MR, Calzone K, Rebbeck TR and Weber BL: Germline TP53 mutations in breast cancer families with multiple primary cancers: is TP53 a modifier of BRCA-1? J Med Genet 40: e34, 2003

26. Bonafé M, Ceccarelli C, Farabegoli F, et al: Retention of the p53 codon 72 arginine is associated with a reduction of disease-free and overall survival in arginine/proline heterozygous breast cancer patients. Clin Cancer Res 9: 4860-4864, 2003.

27. Powell BL, van Staveren IL, Roosken P, Grieu F, Berns EM and Iacopetta B: Associations between common polymorphisms in TP53 and p21WAF1/Cip1 and phenotypic features of breast cancer. Carcinogenesis 23: 311-315, 2002.

28. Kalemi TG, Lambropoulos AF, Gueorguiev M, Chrisafi S, Papazisis KT and Kotsis A: The association of p53 mutations and p53 codon 72, Her 2 codon 655 and MTHFR C677T polymorphisms with breast cancer in Northern Greece. Cancer Lett 222: 57-65, 2005.

29. Weston A and Godbold JH: Polymorphisms of H-ras-1 and p53 in breast cancer and lung cancer: a meta-analysis. Environ Health Perspect 105: 919-926, 1997.
30. Papadakis EN, Dokianakis DN and Spandidos DA: P53 codon 72 polymorphism as a risk factor in the development of breast cancer. Mol Cell Biol Res Commun 3: 389-392, 2000.

31. Tendências Demográficas: uma análise da população com base com base nos resultados dos Censos Demográficos 1940 e 2000: Tendências demográficas no período de 1940/2000: Instituto Brasileiro de Geografia e Estatísitica (IBGE); Rio de Janeiro, 2007.

32. Miller SA: A simple salting out procedure for extracting DNA from human nucleated cells. Nucleic Acids Res 16: 1215, 1988

33. Leistner-Segal S, Pilger DA and Segal F: TP53 gene R72P polymorphism analysis in patients with Barrett esophagus. Cancer Genet Cytogenet 170: 76-77, 2006.

34. Ohayon T, Gershoni-Baruch R, Papa MZ, Menachem TD, Barzilai SE and Friedman E: The R72P P53 mutation is associated with familial breast cancer in Jewish women. Br J Cancer 92. 1144-1148, 2005.

35. Storey A, Thomas M, Kalita A, et al: Role of a p53 polymorphism in the development of human papilloma-virus-associated cancer. Nature 393: 229-234, 1998.

36. Crook T, Ludwig RL, Marston N, et al: Sensitivity of p53 lysine to ubiquitin-directed degradation targeted by human papillomavirus E6. Virology 217: 285-292, 1996.

37. Wang YC, Chen CY, Chen SK, Chang YY and Lin P: p53 codon 72 polymorphism in Taiwanese lung cancer patients: association with lung cancer susceptibility and prognosis. Clin Cancer Res 5: 129-134, 1999.

38. Pierce LM, Sivaraman L, Chang W, et al: Relationships of TP53 codon 72 and HRAS1 polymorphisms with lung cancer risk in an ethnically diverse population. Cancer Epidemiol Biomarkers Prev 9: 1199-1204, 2000.

39. Lima JM, Serafim PVP, Silva IDCG and Forones NM: Estudo do polimorfismo genético no gene p53 (códon 72) em câncer colorretal. Arq Gastroenterol 43: 8-13, 2006

40. Soulitzis N, Sourvinos G, Dokianakis DN and Spandidos DA: P53 codon 72 polymorphism and its association with bladder cancer. Cancer Lett 179: 175-183, 2002.

41. O'Connor DP, Kay EW, Leader M, Atkins GJ, Murphy GM and Mabruk MJEMF: P53 codon 72 polymorphism and human papillomavirus associated skin cancer. J Clin Pathol 54: 539-542, 2001.

42. Själander A, Birgander R, Hallmans G, Cajander S, Lenner P, Athlin L, Beckman G and Beckman L: p53 polymorphisms and haplotypes in breast cancer. Carcinogenesis 17: 1313-1316, 1996.

43. Keshava C, Frye BL, Wolff MS, McCalies EC and Weston A: Walf-1 (p21) and p53 polymorphisms in breast cancer. Cancer Epidemiol Biomarkers Prev 11: 127-130, 2002.

44. Tommiska J, Eerola H, Heinonen M, Tallita J, et al: Breast cancer patients with p53 Pro72 homozygous genotype have a poorer survival. Clin Cancer Res 11: 5098-5103, 2005.

45. Buyru N, Altinisik J, Demokan S and Dalay N: p53 genotypes and haplotypes associated with risk of breast cancer. Cancer Detect Prev 31: 207-213, 2007.

46. Soussi T and Béroud C: Assessing TP53 status in human tumours to evaluate clinical outcome. Nat Rev 1: 233-240, 2001.

47. Damin APS, Frazzon APG, Damin DC, Roehe A, Hermes V, Zettler C and Alexandre COP: Evidence for an association of TP53 codon 72 polymorphism with breast cancer risk. Cancer Detect Prev 30: 523-529, 2006.

48. Noma C, Miyoshi Y, Taguchi T, Tamaki Y and Noguchi S: Association of p53 genetic polymorphism (Arg72Pro) with estrogen receptor positive breast cancer risk in Japanese women. Cancer Lett 210: 197-203, 2004.

49. Mabrouk I, Baccouche S, El-Abed R, et al: No evidence of correlation between $\mathrm{p} 53$ codon 72 polymorphism and risk of bladder or breast carcinoma in Tunisian patients. Ann NY Acad Sci 1010: 764-770, 2003

50. Suspitsin EM, Buslov KG, Grigoriev MY, et al: Evidence against involvement of $\mathrm{p} 53$ polymorphism in breast cancer predisposition. Int J Cancer 103: 413-433, 2003

51. Weston A, Pan C, Ksieski B, et al: p53 haplotype determination in breast cancer. Cancer Epidemiol Biomarkers Prev 6: 105-112, 1997.

52. Han W, Kang D, Park IA, Kim SW, Bae JY, Chung KW and Noh DY: Associations between breast cancer susceptibility gene polymorphisms and clinicopathological features. Clin Cancer Res 10: 124-130, 2004.

53. Goode EL, Dunning AM, Kuschel B, Healey CS, Day NE, Ponder BAJ, Easton DF and Pharoah PPD: Effect of germ-line genetic variation on breast cancer survival in a population-based study. Cancer Res 62: 3052-3057, 2002.

54. Baccouche S, Mabrouk I, Said S, Mosbah A, Jlidi R and Gargouri A: A more accurate detection of codon 72 polymorphism and LOH of the TP53 gene. Cancer Lett 189: 91-96, 2003. 